\title{
SYNTHESIS, CHARACTERIZATION, ANTIMICROBIAL AND MOLECULAR DOCKING STUDY OF BENZOOXADIAZOLE DERIVATIVES
}

\author{
Amel Mohson Naji ${ }^{1}$, Ahmed Mutanabbi Abdula ${ }^{2} \bowtie$, Olfat A. Nief ${ }^{2}$, Ebtihal K. Abdullah ${ }^{3}$
}

https://doi.org/10.23939/chcht16.01.025

\begin{abstract}
In this study, a series of new1,2,5-oxadiazole compounds derived from 4-chloro-7-nitro-benzo 1,2,5oxadiazole was synthesized using different organic procedures. The resulting derivatives were chemically characterized and their structures were confirmed by FTIR and NMR analysis. All the compounds were also evaluated for their antibacterial and antifungal activity against four types of pathogenic bacteria: S.aureus, S.epidermidis (as gram-negative bacteria), E.coli, Klebsiella spp. (as gram-positive bacteria) and the fungus Candida albicans using the agar well diffusion method. The synthesized oxadiazole derivatives exhibited significant antibacterial and moderate antifungal activities. Exploring the binding between the potent synthesized derivative 8 within the active site of glucosamine-6phosphate synthase, the target enzyme for the antimicrobial agents was achieved using Autodock 4.2 package. The interaction modes of the generated conformers inside the binding pocket were found to enhance the in vitro results, and strongly recommended the new derivatives as promising antimicrobial agents.
\end{abstract}

Keywords: 1,2,5-oxadiazole, furazans, antibacterial, antifungal, docking.

\section{Introduction}

Over the past few decades, the main goal of researchers has been the investigation and synthesis of new drugs with a lower microbial resistance, overcoming the threat to the health of human life. ${ }^{1-4}$ Several efforts related to this research area continuously made to develop more effective antimicrobial agents. Notably, oxadiazolebased compounds and derivatives are a promising

\footnotetext{
${ }^{1}$ Department of Optics Techniques, Dijlah University College, Baghdad, Iraq

${ }^{2}$ Department of Chemistry, College of Science, Mustansiriyah

University, Baghdad, Iraq

${ }^{3}$ Department of Chemistry, College of Science, Tikrit University, Tikrit, Iraq

ahm.chem@yahoo.com

(c) Naji, A.M.; Abdula, A.M.; Nief, O.A.; Abdullah, E.K., 2022
}

candidate and have attracted considerable attention in medicinal chemistry due to their diverse medicinal potential. $^{5,6}$ These important compounds can be prepared by several routes and are still developing, according to the literature. ${ }^{7-10}$ The oxadiazoles are heterocyclic compounds of a five-membered ring having two carbons, one oxygen and two nitrogen atoms, resulting from furan through the replacement of two methylene groups $(-\mathrm{CH}=)$ by two pyridine type nitrogen $(-\mathrm{N}=) .{ }^{11,12}$ There are different isomeric forms of 1,3,4-oxadiazole as follows: 1,2,5oxadiazole, 1,2,4-oxadiazole and 1,2,3-oxadiazole. Among them, 1,3,4-oxadiazole and 1,2,4-oxadiazole are of significant interest in medicinal chemistry. ${ }^{13,14}$ The ability of the oxadiazoles to undergo several reactions including thermal, photochemical, electrophilic and nucleophilic substitution reactions ${ }^{15,16}$ has made them suitable for widespread medical applications such as being used as anticancer, antileukemia, ${ }^{17}$ antimicrobial, ${ }^{18,19}$ antiinflammatory, ${ }^{20,21}$ antipsychotics, ${ }^{22}$ anticonvulsant, ${ }^{23}$ antioxidant, ${ }^{24}$ anti-HIV, ${ }^{25}$ anti-malarial, muscle relaxants, antparasitic agent, ${ }^{26}$ and anti-tumor agents. ${ }^{6}$ Moreover, oxadiazoles and their derivatives are also called furazans and selected to be the main cores of the final medicinal products on the basis of quantitative structure-activity relationship (QSAR) studies, involving mathematical correlations between quantitative biological activities of a drug as a function of certain physical, chemical or structural characteristics of the molecule. ${ }^{27}$ Besides the medicinal importance of the oxadiazoles, they are used extensively in the field of materials chemistry so that their isomer moieties can be applied either as a small molecule or polymers for efficient use in the field of materials science, particularly optics, ${ }^{28,29}$ highly energetic materials, ${ }^{30}$ liquid crystalline compounds $^{31}$ and corrosion inhibitors. ${ }^{32}$

The present manuscript illustrates the synthesis of new 1,2,5-oxadiazole derivatives with diverse functionalized moiety by reducing the nitro group of 4chloro-7-nitrobenzofurazan followed by the substitution reaction of the compound $\mathbf{1}$ with ethyl bromoacetate to afford the compound $\mathbf{2}$. Hydrazone derivative $\mathbf{3}$ has been obtained from the benzooxadiazole derivative $\mathbf{2}$ by the direct substitution with hydrazine hydrate. Pyridazine and 
phthalazine derivatives (4 and 5 ) were obtained from the compound 3 by the reaction with the corresponding anhydride (Scheme 1). The Schiff base derivative 6 was synthesized by the reaction of the derivative 3 with pyridine-4-carbaldehyde. The cycloadditionreaction of the compound 6 with thioglycolic acid and chloroacetyl chloride afforded novel derivatives 7 and $\mathbf{8}$. The 1,3oxazepan derivatives $\mathbf{9}$ and $\mathbf{1 0}$ were synthesized by the cyclization reaction of the compound $\mathbf{6}$ with the corresponding anhydride. The synthesized derivatives were screened for their antimicrobial activity against different species using a well diffusion method. Docking approach for the $\beta$-lactam derivative $\mathbf{8}$, one of the most potent discovered hit, within the active site of glucosamine-6-phosphate synthase ${ }^{33}$ is achieved to explain the interactions between the generated conformers and the amino acid residues of the enzyme binding pocket. In this case, Autodock 4.2, the effective tool for exploring the binding affinity of small molecule to protein or enzyme target ${ }^{34}$ is employed.

\section{Experimental}

\subsection{Materials and Synthetic Methods}

All the chemicals were purchased from Fluka and Sigma Aldrich Company and used without any further purification. Melting points were determined on a Stuart melting point (digital SMP 30) apparatus using an open capillary tube method, and were reported uncorrected. Infrared spectra were performed on a Perkin-Elmer FT-IR spectrometer. All NMR spectra were recorded on DMSOd6 using a BrukerDRX $300 \mathrm{MHz}$ instrument. The reaction monitored by a thin layer chromatography (TLC) on Merck silica-coated plates using hexane:ethyl acetate mixture.

Synthesis of 4-amino 7-chloro-[2,1,3] benzoxadiazole (1). This compound was prepared as described in [35].

Synthesis of 7-chloro-[4-amino acetic acid ethyl ester]-[2,1,3]-benzoxadiazole (2). The reagent ethylbromoacetate $(0.0025 \mathrm{~mol}, 0.4 \mathrm{~g})$ was added to a mixture of the compound $1(0.0025 \mathrm{~mol}, 0.56 \mathrm{~g})$ and potassium carbonate $\mathrm{K}_{2} \mathrm{CO}_{3}(0.005 \mathrm{~mol}, 1.1 \mathrm{~g})$ in DMF $(25 \mathrm{~mL})$ as a solvent, then refluxed for $9 \mathrm{~h}$. The precipitate formed was filtered off by removing the solvent under reduced pressure, washed with water and recrystallized from ethanol.

Light yellow; yield $73 \%$; m.p. 425-427 K. FT-IR $\left(\mathrm{cm}^{-1}\right): 3212(\mathrm{~N}-\mathrm{H}), 3068(\mathrm{C}-\mathrm{H}$ stretching aromatic ring $)$, 2926, 2866 (C-H stretching aliphatic), $1745(\mathrm{C}=\mathrm{O}), 1610$ $(\mathrm{C}=\mathrm{N}), 1599\left(\mathrm{C}=\mathrm{C}_{\mathrm{Ar}}\right), 1217(\mathrm{C}-\mathrm{O}) ;{ }^{1} \mathrm{H}$ NMR $(\mathrm{DMSO}) \delta$ ppm: 7.20-6.50 (dd, 2H, Ar-H), $5.58(\mathrm{~s}, \mathrm{~N}-\mathrm{H}), 5.18$ (s, $2 \mathrm{H}, \mathrm{N}-\mathrm{CH}_{2}-\mathrm{CO}-$ ), 4.04-4.15 (q, $2 \mathrm{H},-\mathrm{OCH}_{2}-$ ), 1.11-1.12 $\left(\mathrm{t}, 3 \mathrm{H}, \mathrm{CH}_{3}\right) ;{ }^{13} \mathrm{C} \mathrm{NMR}\left(\mathrm{DMSOd}_{6}\right) \delta$ ppm: 167.8, 146.9, 130.0,128.0, 115.7, 112.9, 67.8, 55.0, 17.8 .
Synthesis of 7-chloro-[2,1,3]benzoxadiazol-4ylamino)-acetic acid hydrazide (3). A mixture of the compound $2(0.001 \mathrm{~mol}, 0.26 \mathrm{~g})$ and hydrazine hydrate $(1.0 \mathrm{~mL}, 80 \%)$ dissolved in an absolute ethanol $(20 \mathrm{~mL})$ in a round bottle flask with a short reflux condenser was gently heated under reflux for $15 \mathrm{~h}$. The resultant solution was kept to settle and form hydrazide crystals, followed by filtration, washing with cold water, drying and recrystallization from ethanol.

Yellow; yield $67 \%$; m.p. 435-437 K. FT-IR $\left(\mathrm{cm}^{-1}\right): 3333,3225\left(\mathrm{NH}, \mathrm{NH}_{2}\right), 3126(\mathrm{~N}-\mathrm{H}), 3047(\mathrm{C}-$ $\left.\mathrm{H}_{\mathrm{Ar}}\right), 2980,2815\left(\mathrm{C}-\mathrm{H}_{\mathrm{Alph}}\right), 1683(\mathrm{C}=\mathrm{O}), 1614(\mathrm{C}=\mathrm{N})$, 1591, $1556\left(\mathrm{C}=\mathrm{C}_{\mathrm{Ar}}\right), 1285(\mathrm{C}-\mathrm{O}) ;{ }^{1} \mathrm{H}$ NMR $(\mathrm{DMSO}) \delta$ ppm: 7.20-6.20 (dd, 2H, Ar-H), $5.58(\mathrm{~s}, 1 \mathrm{H},-\mathrm{NH}), 4.80$ (s, $\left.2 \mathrm{H},-\mathrm{NH}_{2}\right), 4.80(\mathrm{~s}, \mathrm{H},-\mathrm{ArNH}-), 4.40\left(\mathrm{~s}, 2 \mathrm{H}, \mathrm{CH}_{2}\right)$; ${ }^{13}$ C NMR (DMSO-d $\left.\mathrm{d}_{6}\right) \delta$ ppm: 177.0, 145.8,130.8, 128.0, 125.7, 115.7, 112.8, 54.3.

Synthesis of pyridazine derivatives $(\mathbf{4}, \mathbf{5})$. To the round bottle flask containing the compound $3(0.001 \mathrm{~mol}$, $0.24 \mathrm{~g}$ ), $0.001 \mathrm{~mol}$ of appropriate acid anhydride (maleic anhydride and phthalic anhydride) and $15 \mathrm{~mL}$ of glacial acetic acid were added dropwise and the mixture was refluxed for $22 \mathrm{~h}$. The reaction crude was filtered, then the filtrate neutralized with $10 \% \mathrm{KOH}$ solution to obtain the product which was washed several times with water, dried in air and finally recrystallized from chloroform.

$$
\text { 3-(7-chloro-[2,1,3]benzoxadiazol-4-ylamino)- }
$$

propionyl]-1,2-dihydro-pyridazine-3, 6-dione (4). Pale yellow; yield $68 \%$; m.p. 478-480 K. FT-IR $\left(\mathrm{cm}^{-1}\right): 3198$ $(\mathrm{N}-\mathrm{H}), 3014\left(\mathrm{C}-\mathrm{H}_{\mathrm{Ar}}\right), 2978,2829\left(\mathrm{C}-\mathrm{H}_{\mathrm{Alph}}\right), 1732(\mathrm{C}=\mathrm{O}$ imid), $1698(\mathrm{C}=\mathrm{O}$ amide $), 1610(\mathrm{C}=\mathrm{N}), 1581,1566$ $\left(\mathrm{C}=\mathrm{C}_{\mathrm{Ar}}\right) ;{ }^{1} \mathrm{H}$ NMR $(\mathrm{DMSO}) \delta \mathrm{ppm}: 8.30(\mathrm{~s}, 1 \mathrm{H},-\mathrm{NH}-$ $\mathrm{CO}), 7.90-6.90(\mathrm{~m}, 4 \mathrm{H}, \mathrm{Ar}-\mathrm{H}, \mathrm{CH}=\mathrm{CH}), 5.77(\mathrm{~s}, 1 \mathrm{H},-$ ArNH-), $4.50\left(\mathrm{~s}, 2 \mathrm{H}, \mathrm{NHCH}_{2}\right) ;{ }^{13} \mathrm{C}$ NMR $\left(\mathrm{DMSO}_{-} \mathrm{d}_{6}\right) \delta$ ppm: 168.0, 165.0, 163.0, 109.0, 145.0, 58.0.

3-(7-chloro- $[2,1,3]$ benzoxadiazol-4-ylamino)propionyl]-2, 3-dihydro-phthalazine-1,4-dione (5). Off white; yield $56 \%$; m.p. 462-464 K. FT-IR $\left(\mathrm{cm}^{-1}\right): 3178$ $(\mathrm{N}-\mathrm{H}), 3067\left(\mathrm{C}-\mathrm{H}_{\mathrm{Ar}}\right), 2973,2834\left(\mathrm{C}-\mathrm{H}_{\mathrm{Alph}}\right), 1737(\mathrm{C}=\mathrm{O}$ imid), $1693(\mathrm{C}=$ amide $), 1612(\mathrm{C}=\mathrm{N}), 1591,1567\left(\mathrm{C}=\mathrm{C}_{\mathrm{Ar}}\right)$; ${ }^{1} \mathrm{H}$ NMR (DMSO) $\delta$ ppm: 6.0-7.9 (m, 6H, Ar-H), $8.0(\mathrm{~s}$, $\mathrm{H},-\mathrm{NH}-\mathrm{CO}), 4.32(\mathrm{~s}, \mathrm{H}, \mathrm{ArNH}), 3.85\left(\mathrm{~s}, 2 \mathrm{H}, \mathrm{CH}_{2}\right)$; ${ }^{13} \mathrm{C}$ NMR (DMSO-d 6 ) $\delta$ ppm: 58, 109, 149, 163, 165, 168.

Synthesis of (7-chloro-[2,1,3]-benzooxadiazol-4ylamino)-aceticacidpyridin-4-ylmethylene-hydrazide (6). A mixture of the compound $3(0.001 \mathrm{~mol}, 2.4 \mathrm{~g})$, 4pyridine carboxaldehyde $(0.001 \mathrm{~mol}, 0.12 \mathrm{~g})$ and methanol as a solvent in a round bottle flask fitted with a short reflux condenser was stirred under heating for $12 \mathrm{~h}$. After completing the reaction, (monitored by TLC), the solution was kept to settle for some time. The resultant solid product was filtered, dried and purified from ethanol.

Light yellow; yield $76 \%$; m.p. 521-522 K; FT-IR $\left(\mathrm{cm}^{-1}\right): 3095\left(\mathrm{C}-\mathrm{H}_{\mathrm{Ar}}\right), 2973,2834\left(\mathrm{C}-\mathrm{H}_{\mathrm{Alph}}\right), 1591,1567$ 
$\left(\mathrm{C}=\mathrm{C}_{\mathrm{Ar}}\right), 3176(\mathrm{~N}-\mathrm{H}), 1699(\mathrm{C}=\mathrm{O}$ amide $), 1628(\mathrm{C}=\mathrm{N})$; ${ }^{1} \mathrm{H}$ NMR (DMSO) $\delta$ ppm: $4.19\left(\mathrm{~s}, 2 \mathrm{H},-\mathrm{CH}_{2}\right), 5.2(\mathrm{~s} .1 \mathrm{H},-$ $\mathrm{NH}), 7.3(\mathrm{~s}, \mathrm{H},(\mathrm{CONH}), 7.6-8.2(\mathrm{~m}, 6 \mathrm{H}, \mathrm{Ar}-\mathrm{H}), 8.8(\mathrm{~s}$, $1 \mathrm{H}, \mathrm{CH}=\mathrm{N}) ;{ }^{13} \mathrm{C}$ NMR $\left(\mathrm{DMSO}-\mathrm{d}_{6}\right) \delta$ ppm: $58,107,112$, 149, 153, 174.

Synthesis of 2-(7-Chloro-benzo[2, 1, 3] oxadiazol4-ylamino)-N-(4-oxo-2-pyridin-4-yl-thiazolidin-3-yl)-

acetamide (7). To the mixture of the compound $\mathbf{6}$ $(0.001 \mathrm{~mol}, 0.33 \mathrm{~g})$ and $\mathrm{ZnCl}_{2}(0.01 \mathrm{~g})$ dissolved in chloroform $(25 \mathrm{~mL})$ in a round bottle flask, thioglycolic acid $(0.005 \mathrm{~mol}, 0.46 \mathrm{~g})$ was added and the reaction mixture was refluxed for $10 \mathrm{~h}$. After refluxing, the solvent was removed under pressure. The resultant residue was treated by $50 \mathrm{~mL}$ of $10 \% \mathrm{NaHCO}_{3}$ solution to remove the excess of thioglycolic acid, washed with water, dried in air and recrystallized from DMF.

Light yellow; yield $76 \%$; m.p. 471-473 K; FT-IR $\left(\mathrm{cm}^{-1}\right): 3018\left(\mathrm{C}-\mathrm{H}_{\mathrm{Ar}}\right), 2922,2852\left(\mathrm{C}-\mathrm{H}_{\text {Aliph }}\right), 1581,1558$ $\left(\mathrm{C}=\mathrm{C}_{\mathrm{Ar}}\right), 3151(\mathrm{~N}-\mathrm{H}), 1712(\mathrm{C}=\mathrm{O}$ thiazolidinone $), 1610$ $(\mathrm{C}=\mathrm{N}), 1683\left(\mathrm{C}=\mathrm{O}\right.$ amide). ${ }^{1} \mathrm{H}$ NMR $(\mathrm{DMSO}) \delta \mathrm{ppm}$ : $8.02(\mathrm{~s}, 1 \mathrm{H},-\mathrm{NH}), 7.25-7.76(\mathrm{~m}, 6 \mathrm{H}, \mathrm{Ar}-\mathrm{H}), 5.54(\mathrm{~s}, 1 \mathrm{H}$, $\mathrm{CH}-\mathrm{N}), 4.89\left(\mathrm{~s}, 2 \mathrm{H},-\mathrm{CH}_{2}\right), 3.37-3.95\left(\mathrm{~d}, 2 \mathrm{H}, \mathrm{S}-\mathrm{CH}_{2}\right)$; ${ }^{13} \mathrm{C}$ NMR (DMSO-d $\left.\mathrm{d}_{6}\right) \delta$ ppm: 58.8, 171, 38, 58.1, 168, 104, 112, 158.

Synthesis of 2-(7-chloro- $[2,1,3]$ benzoxadiazol-4ylamino)-N-(3-chloro-2-oxo-4-pyridin-4-yl-azetidin-1-yl)acetamide (8). This derivative was synthesized according to the procedure described in [36]. The compound $\mathbf{6}$ $(0.001 \mathrm{~mol}, 0.33 \mathrm{~g})$ and trimethylamine $(0.025 \mathrm{~mol}, 2.5 \mathrm{~g})$ dissolved in dioxane $(10 \mathrm{~mL})$ was stirred in a cold water bath at $273-278 \mathrm{~K}$. Afterward, chloroacetylchloride ( $0.01 \mathrm{~mol}, 1.12 \mathrm{~g})$ was added drop by drop. The mixture was stirred for $3 \mathrm{~h}$, then refluxed for $9 \mathrm{~h}$. The solvent was removed under reduced pressure, and the collected product was washed with water, dried and recrystallized from chloroform.

Deep yellow; yield $66 \%$; m.p. 499-501 K; FT-IR $\left(\mathrm{cm}^{-1}\right): 3076\left(\mathrm{C}-\mathrm{H}_{\mathrm{Ar}}\right), 2923,2858\left(\mathrm{C}-\mathrm{H}_{\text {Aliph }}\right), 1581,1557$ $\left(\mathrm{C}=\mathrm{C}_{\mathrm{Ar}}\right), 3191(\mathrm{~N}-\mathrm{H}), 1616(\mathrm{C}=\mathrm{N}), 1710(\mathrm{C}=\mathrm{O} \beta$-lactam $)$; ${ }^{1} \mathrm{H}$ NMR (DMSO) $\delta$ ppm: $8.77(\mathrm{~s}, 1 \mathrm{H},-\mathrm{NH}), 7-8.6(\mathrm{~m}$, $6 \mathrm{H}, \mathrm{Ar}-\mathrm{H}), 5.3(\mathrm{~s}, 1 \mathrm{H}, \mathrm{Cl}-\mathrm{CH}), 3.8(\mathrm{~s}, 2 \mathrm{H}, \mathrm{CH} 2), 4.2(\mathrm{~s}$, $1 \mathrm{H}, \mathrm{N}-\mathrm{CH}$ ) $;{ }^{13} \mathrm{C}$ NMR (DMSO-d6) $\delta$ ppm: $170,57,62$, $164,64,112,153$.

Synthesis of 1,3-oxazepan derivatives $(\mathbf{9}, \mathbf{1 0})$. These derivatives were synthesized according to the procedure introduced by Greenwood et al.$^{37}$ A mixture of the compound $6(0.001 \mathrm{~mol}, 0.33 \mathrm{~g})$ and the corresponding anhydride (maleic or phthalic anhydride) (0.001 mol) was refluxed for $24 \mathrm{~h}$ in $20 \mathrm{~mL}$ of chloroform as a solvent. After completing the reaction (monitored by thin layer chromatography), the crude was filtered and the solvent removed under reduced pressure. The resultant product was collected and purified from ethanol. 2-(7-chloro- $[2,1,3]$ benzoxadiazol-4-ylamino)- $\mathrm{N}$ (4,7-dioxo-2-pyridin-4-yl-4,7-dihydro-[1,3] oxazepin-3yl)-acetamide (9). Light yellow; yield 69\%; m.p. 440$441 \mathrm{~K}$; FT-IR $\left(\mathrm{cm}^{-1}\right): 3051$ (CH aromatic), 2939, 2876 ( $\mathrm{CH}$ aliphatic), 1593, 1539 ( $\mathrm{C}=\mathrm{C}$ aromatic), $1687(\mathrm{C}=\mathrm{O}$ lactam), $1729(\mathrm{C}=\mathrm{O}$ lactone $), 1167(\mathrm{C}-\mathrm{O}$ str. $), 1236(\mathrm{C}-$ $\mathrm{N}) ;{ }^{1} \mathrm{H}$ NMR (300 MHz, DMSO-d6, $\delta$, ppm): 6.1-6.8 (dd, $2 \mathrm{H}, \mathrm{CH}=\mathrm{CH}), 7.4(\mathrm{~s}, 1 \mathrm{H}, \mathrm{CH}-\mathrm{N}), 7.9(\mathrm{~s}, 1 \mathrm{H}, \mathrm{NNHCO})$, 4.57 (s, 1H, NH Ar), 7.6-8.6 (m, 6H, Ar), 3.9 (s, 2H, NH$\mathrm{CH} 2 \mathrm{CO}) ;{ }^{13} \mathrm{C}$ NMR DMSO-d 6 : 58, 87, 106, 125, 150, 136.6, 136.9, 165,167, 170.

2-(7-chloro- $[2,1,3]$ benzoxadiazol-4-yl amino)- $N$ (5,9-dioxo-7-pyridin-4-yl-5,9-dihydro-6-oxa-8-aza-

benzocyclohepten-8-yl)-acetamide (10). Light yellow; yield $57 \%$; m.p. 505-507 K; FT-IR $\left(\mathrm{cm}^{-1}\right)$ : $3097 \mathrm{v}(\mathrm{CH}$ aromatic), 2979, $2896 v$ ( $\mathrm{CH}$ aliphatic), 1611, $1569 v$ ( $\mathrm{C}=\mathrm{C}$ aromatic), $1689 v(\mathrm{C}=\mathrm{O}$ lactam $), 1731 v(\mathrm{C}=\mathrm{O}$ lactone $)$, $1157 v$ (C-O str.), $1242 v(\mathrm{C}-\mathrm{N}) ;{ }^{1} \mathrm{H}$ NMR $(300 \mathrm{MHz}$, DMSO-d6, $\delta, \mathrm{ppm}): 7.3(\mathrm{~s}, 1 \mathrm{H}, \mathrm{CH}-\mathrm{N}), 8.2(\mathrm{~s}, 1 \mathrm{H}$, NHCO), 4.6 (s,1H, NH Ar), 6.6-8.6 (m, 10H, Ar), 3.9 (s, $2 \mathrm{H}, \mathrm{NH}-\mathrm{CH} 2 \mathrm{CO}) ;{ }^{13} \mathrm{C}$ NMR DMSO-d $\mathrm{d}_{6}: 57.8,86.7,105$, $112,150,165,167,170$.

\subsection{Antimicrobial Evaluation}

In vitro antimicrobial effects of benzooxadiazole derivatives were tested against four bacterial strains, namely, S.aureus, S.epidermidis (as gram-negative bacteria), E.coli, Klebsiella spp. (as gram-positive bacteria) and the fungus Candida albicans. The antimicrobial activity was determined using the agar well diffusion method. ${ }^{38}$ Dimethyl sulfoxide acted as a controller, and the test was carried out at a concentration of $100 \mathrm{mg} / \mathrm{mL}$ and by adding $50 \mu \mathrm{L}$ to each disk (i.e., $5 \mu \mathrm{g} /$ disk) using DMSO as a solvent. The fungi and bacteria were subcultured in agar and potato dextrose agar media. For antibacterial and antifungal activities, the inhibition zone was compared with the standard drug after incubation at 310 and $298 \mathrm{~K}$ for 24 and $72 \mathrm{~h}$, respectively. The results obtained are presented in Table 1.

\subsection{Docking Study}

As described in our previous study, ${ }^{39}$ the pdb file format of the receptor was obtained from the Protein Data Bank (PDB code 1MOQ) and used as a rigid molecule. The missing hydrogens were added to the amino acid residues, and the water molecules were removed. The compound 8 was drawn using ChemDrawUltra 7.0 as mol file, and the open Babel 2.3.1 software was used to make the pdb file. The docking study was achieved using grid dimensions of 30.5, 17.5 and -2.2. Lamarckian Genetic Algorithm with a population size of 150,10 runs and a maximum number of energy evaluations of 2,500,000 was 
also employed. The docking protocol included a maximum number of generations of 27,000.

\section{Results and Discussion}

\subsection{Synthesis and Characterization}

As known, one of the signifcant features in the chemistry of 4-amino7-chloro-[2,1,3]benzoxadiazole is their use as key starting materials for further transformations. Briefly, the compound 1 was condensed with ethyl bromoacetate to obtain derivative $\mathbf{2}$ as illustrated by Scheme 1. On the other hand, the compound 2 was condensed with $80 \%$ hydrazine hydrate to prepare acetic acid hydrazide 3 . Various substitutions carried out on the compound $\mathbf{3}$ with appropriate acid anhydride (maleic anhydride and phthalic anhydride) yielded the compounds $\mathbf{4}$ and $\mathbf{5}$, respectively. The compound $\mathbf{3}$ was also condensed with 4-pyridine carboxaldehyde to afford benzoxadiazole derivative $\mathbf{6}$. Furthermore, the compound 6 was cyclized with thioglycolic acid or chloroacetylchloride, resulting in the corresponding compounds (7 and 8). Finally, the benzoxadiazole derivatives $\mathbf{9}$ and $\mathbf{1 0}$ were obtained from the compound $\mathbf{6}$ by treating it with the corresponding aldehyde in chloroform as a solvent as illustrated in Scheme 1.

The results of FT-IR, ${ }^{1} \mathrm{H}$ and ${ }^{13} \mathrm{C}$ NMR are found to be consistent with the suggested molecular formula of the concerned compounds. The structure of the compound $\mathbf{2}$ was confirmed based on the melting point and their spectral data. The FT-IR spectrum displays a stretching band at $3212 \mathrm{~cm}^{-1}$ related to $\mathrm{NH}$, three bands at 3068 , 2926 and $2866 \mathrm{~cm}^{-1}$ due to $\mathrm{CH}$ of aromatic and aliphatic vibrations. The two bands at 1745 and $1599 \mathrm{~cm}^{-1}$ confirm the stretching of $\mathrm{C}=\mathrm{O}$ and $\mathrm{C}=\mathrm{C}$ of aromatic ring. The ${ }^{1} \mathrm{H}$ NMR of benzoxadiazole derivative 2 shows the following signals: doublet in the region of 7.20-6.50 ppm which can be attributed to two aromatic protons, singlet signal at $5.58 \mathrm{ppm}$ related to $\mathrm{NH}$, while the singlet at $5.18 \mathrm{ppm}$ is due to methylene protons. The quartet signal at $4.04-4.15 \mathrm{ppm}$ and the triplet at $1.11-1.12 \mathrm{ppm}$ related to $\mathrm{CH}_{2}$ and $\mathrm{CH}_{3}$ of $\mathrm{COOC}_{2} \mathrm{H}_{5}$ group. The FT-IR spectrum of the compound $\mathbf{3}$ displays sharp peaks at 3333,3225 and $3126 \mathrm{~cm}^{-1}$, which are assigned to the $\mathrm{NH}$ stretching vibration of hydrazidean $\mathrm{NHCO}$ groups. Also, the ${ }^{1} \mathrm{H}$ and ${ }^{13} \mathrm{C}$ NMR data (see experimental section) confirm the compound structure. The ${ }^{1} \mathrm{H}$ NMR spectrum of pyridazine derivative 4 showed a multiplet signal at $6.9-7.9 \mathrm{ppm}$ related to two aromatic and $\mathrm{CH}=\mathrm{CH}$ protons, the singlet signal at $8.3 \mathrm{ppm}$ for $\mathrm{NH}-\mathrm{CO}$ proton. Two singlets observed at 5.77 and $4.5 \mathrm{ppm}$ are due to $\mathrm{Ar}-\mathrm{NH}$ and $\mathrm{CH}_{2}$ protons. The ${ }^{13} \mathrm{C}$ NMR spectrum strongly enhances the structure elucidation. The formation of the Schiff base derivative $\mathbf{6}$ was confirmed by the FT-IR analysis. The FT-IR spectrum showed imine stretching band $(\mathrm{N}=\mathrm{CH})$ at $1628 \mathrm{~cm}^{-1}$ which was accompanied by the disappearance of $\mathrm{NH}_{2}$ stretching band related to the compound 3 (see experimental section). The ${ }^{1} \mathrm{H}$ NMR spectrum of the compound $\mathbf{6}$ showed three singlet signals at 4.19, 5.2 and $7.3 \mathrm{ppm}$ which are assigned to $\mathrm{CH}_{2}, \mathrm{NH}$, and $\mathrm{CO}-\mathrm{NH}$ protons, respectively. The multiplet signal at $7.6-8.2 \mathrm{ppm}$ related to aromatic and $\mathrm{CH}=\mathrm{N}$ protons. The ${ }^{13} \mathrm{C} N M R$ presented in the experimental section confirms the structure elucidation. The structural confirmation of oxothiazolidinone derivative 7 synthesized from the Schiff base derivative 6 by the action of mercapto acetic acid in the presence of anhydrous $\mathrm{ZnCl}_{2}$, was achieved by the FTIR analysis, as well as NMR technique. The FT-IR spectrum showed the following bands: $3151 \mathrm{~cm}^{-1}(\mathrm{NH})$, $1712 \mathrm{~cm}^{-1}(\mathrm{C}=\mathrm{O}$ thiazolidinone $), 1610 \mathrm{~cm}^{-1}(\mathrm{C}=\mathrm{N})$ and $1683 \mathrm{~cm}^{-1}$ ( $\mathrm{C}=\mathrm{O}$ amide). The ${ }^{1} \mathrm{H}$ NMR spectrum showed singlet signals at 5.54 and 4.89 ppm which are assigned to $\mathrm{CH}-\mathrm{N}$ and $\mathrm{CH}_{2}$ protons, respectively. The multiplet signal at $7.25-7.76 \mathrm{ppm}$ is attributed to aromatic protons, while the doublet signals appear at $3.37-3.95 \mathrm{ppm}$ related to $\mathrm{SCH}_{2}$ protons. The ${ }^{13} \mathrm{C}$ NMR signals are presented in the experimental section. As explained previously, 2-(7chloro-[2,1,3] benzoxadiazol-4-ylamino)- $N$-(3-chloro-2oxo-4-pyridin-4-yl-azetidin-1-yl)-acetamide $\mathbf{8}$ was obtained through the reaction of the compound $\mathbf{6}$ with chloroacetyl chloride in the presence of triethyl amine as the catalyst and dioxane as the solvent. The FT-IR spectrum showed stretching bands at $3191 \mathrm{~cm}^{-1}$ for $\mathrm{NH}$ and stretching band at the $1670 \mathrm{~cm}^{-1}$ related to $\mathrm{C}=\mathrm{O}$ of $\beta$ lactam. The ${ }^{1} \mathrm{H}$ NMR spectrum showed singlet signals at 3.8 and $8.77 \mathrm{ppm}$ for $\mathrm{CH}_{2}$ and $-\mathrm{NH}$; singlet signal for $\mathrm{N}-$ $\mathrm{CH}$ at $4.2 \mathrm{ppm}$ and multiplet signals at $7.00-8.60 \mathrm{ppm}$ for aromatic protons, while the $\mathrm{CHCl}$ proton appears as a singlet at $5.3 \mathrm{ppm}$. For more detail about ${ }^{13} \mathrm{C}$ NMR see the experimental section. Alternatively, the compound 6 was cyclized with maleic andphthalic anhydride in chloroform to afford the derivatives $\mathbf{9}$ and 10, respectively. The FT-IR spectral data of the compound $\mathbf{9}$ showed the appearance of absorption bands at 1729 and $1687 \mathrm{~cm}^{-1}$ related to $\mathrm{C}=\mathrm{O}$ group of lactone and lactam, respectively. The ${ }^{1} \mathrm{H}$ NMR spectrum of the compound $\mathbf{9}$ showed the following signals: four singlet signals at 7.4, 7.9, 4.57 and $3.90 \mathrm{ppm}$ related toCH-N, NHCO, $\mathrm{NH}-\mathrm{Ar}$ and $\mathrm{N}-\mathrm{CH}_{2}-\mathrm{CO}$ protons, respectively; multiplet at $7.6-8.6 \mathrm{ppm}$ attributed to six aromatic protons. The ${ }^{13} \mathrm{C}$ NMR signals are presented in the experimental section. 


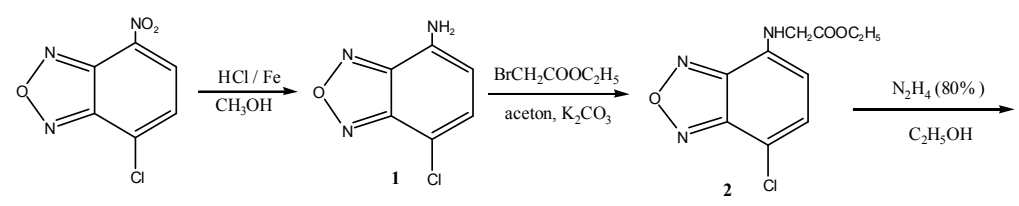<smiles>O=C1CSC(c2ccncc2)N1OCc1ccc(Cl)c2nonc12</smiles><smiles>NCOc1ccc(Cl)c2nonc12</smiles><smiles></smiles><smiles>O=C(Nc1ccc(Cl)c2nonc12)C(=O)n1[nH]c(=O)c2ccccc2c1=O</smiles><smiles></smiles>

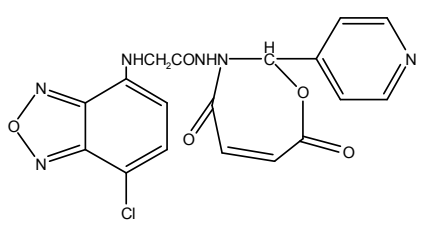

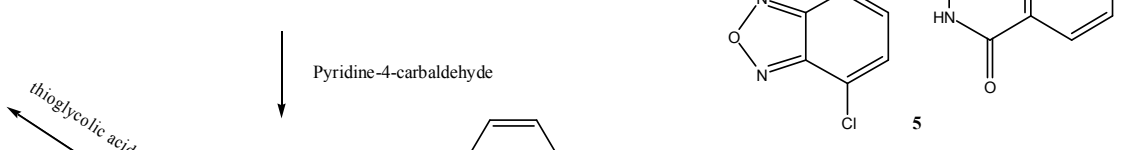

Scheme 1. The synthetic approach for the benzooxadiazole derivatives 1-10

Table 1. The antimicrobial screening activity of the synthesized compounds 4-10

\begin{tabular}{|c|c|c|c|c|c|}
\hline \multirow{2}{*}{$\begin{array}{c}\text { Heterocyclic } \\
\text { derivative }\end{array}$} & \multicolumn{5}{|c|}{ Inhibition zone (mm) at $100 \mathrm{mg} / \mathrm{mL}$} \\
\cline { 2 - 6 } & S. aureus & S. epidermidis & E.coli & Klebsiella spp. & C. albicanus \\
\hline $\mathbf{4}$ & 10 & 10 & - & - & - \\
\hline $\mathbf{5}$ & 10 & 11 & 13 & 15 & 12 \\
\hline $\mathbf{6}$ & 12 & 14 & 14 & 12 & - \\
\hline $\mathbf{7}$ & 15 & 17 & 14 & 14 & 13 \\
\hline $\mathbf{8}$ & 16 & 14 & 10 & 14 & 16 \\
\hline $\mathbf{9}$ & 18 & 16 & 10 & 12 & 15 \\
\hline $\mathbf{1 0}$ & 19 & 12 & 5 & 18 & 15 \\
\hline Amoxicillin & 20 & 21 & - & - & - \\
\hline Nystatin & - & - & - & & 20 \\
\hline
\end{tabular}




\subsection{Antimicrobial Activity}

The synthesized benzooxadiazole derivatives that carry Schiff base, azetidinone, thiazolidinone, pyridazine and 1,3-oxazepan moieties, were found to be accountable for antimicrobial activity. The amoxicillin and nystatin were used as the standard for comparison between antibacterial and antifungal activities, respectively. According to the results of screening inhibition zones shown in Table 1 and Fig. 1, antimicrobial activity caused by various compounds are considered as "highly active" (inhibition zone $\geq 18 \mathrm{~mm}$ ), "moderately active" (inhibition zone 14-17 mm), or "inactive" (inhibition zone $\leq 13 \mathrm{~mm}$ ). While the compound $\mathbf{1 0}$ is highly effective against grampositive type Staphylococcus aureus, it is moderately effective against fungus C.albicanus and ineffective against S.epidemidis and gram-negative bacteria. The compound 9 shows high effectiveness against the gram-positive type Staphylococcus aureus, but has moderate activity toward S.epidemidis, gram-negative Klebsiella spp. and fungus C.albicanus while also being ineffective against gramnegative E.coli. The compound $\mathbf{8}$ is highly effective against gram-negative E.coli, but shows moderate activity against Klebsiella spp., gram-positive bacteria and fungus C.albicanus. The compound 7 is moderately effective against gram-positive and gram-negative types E.coli while also being ineffective against Klebsiella spp. and fungus C.albicanus. The compound $\mathbf{6}$ shows moderate effectiveness towards gram-positive type S.epidemidis and gram-negative bacteria but has no effect towards grampositive Staphylococcus aureus and fungi. Derivative $\mathbf{5}$ shows moderate effectiveness against Klebsiella spp., and is ineffective toward all other bacterial and fungal samples. Likewise, pyridazine derivative 4 shows ineffectiveness against all bacterial and fungal samples.

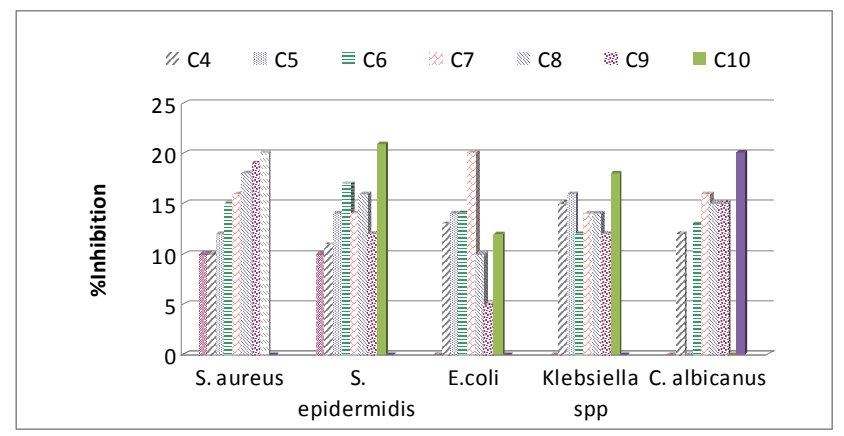

Fig. 1. Antimicrobial evaluation of the synthesized compounds 4-10

\subsection{Docking Study}

The docking approach of the $\beta$-lactam derivative $\mathbf{8}$ against the active site of target enzyme was examined. The following residues: Cysteine 300, Glycine 301,
Threonine 302, Serine 303 and 347, Glutamine 348, Serine 349, Threonine 352, Valine 399, Serine 401, Alanine 602 and Lysine 603 shown in Fig. 2, represent the binding pocket of the enzyme as indicated by the X-ray. ${ }^{40}$ As an effective docking tool, Autodock 4.2 was used for the explanation of the binding energy of active compound inside the known three dimensional structure of the LGlutamine: D-fructose-6- phosphate amidotransferase. The binding of the best building generated conformer for the compound $\mathbf{8}$ inside the binding pocket of enzyme is illustrated in Fig. 3. As indicated by docking parameters (Table 2), the highest binding energy of the generated conformers was $-33.74 \mathrm{~kJ} / \mathrm{mol}$ with an intermolecular energy equal to $-39.98 \mathrm{~kJ} / \mathrm{mol}$. The best generated conformer binds the active site with two hydrogen bonds, the first one with valine 399 and the other one with serine 349 residue in way mimics the enzyme substrate. The second generated conformer fits the enzyme pocket with four $\mathrm{H}$ bonds as indicated by Table 2 with binding energy equal to $-33.24 \mathrm{~kJ} / \mathrm{mol}$ and $1.52 \mu \mathrm{M}$ inhibition constant. The inhibition constant $K_{i}$, intermolecular energy and hydrogen bonds of other conformers were also determined, and are inserted in Table 2 . The binding modes of the $\beta$-lactam derivative $\mathbf{8}$ inside the enzyme cavity explain the potent activity of the discovered hit.

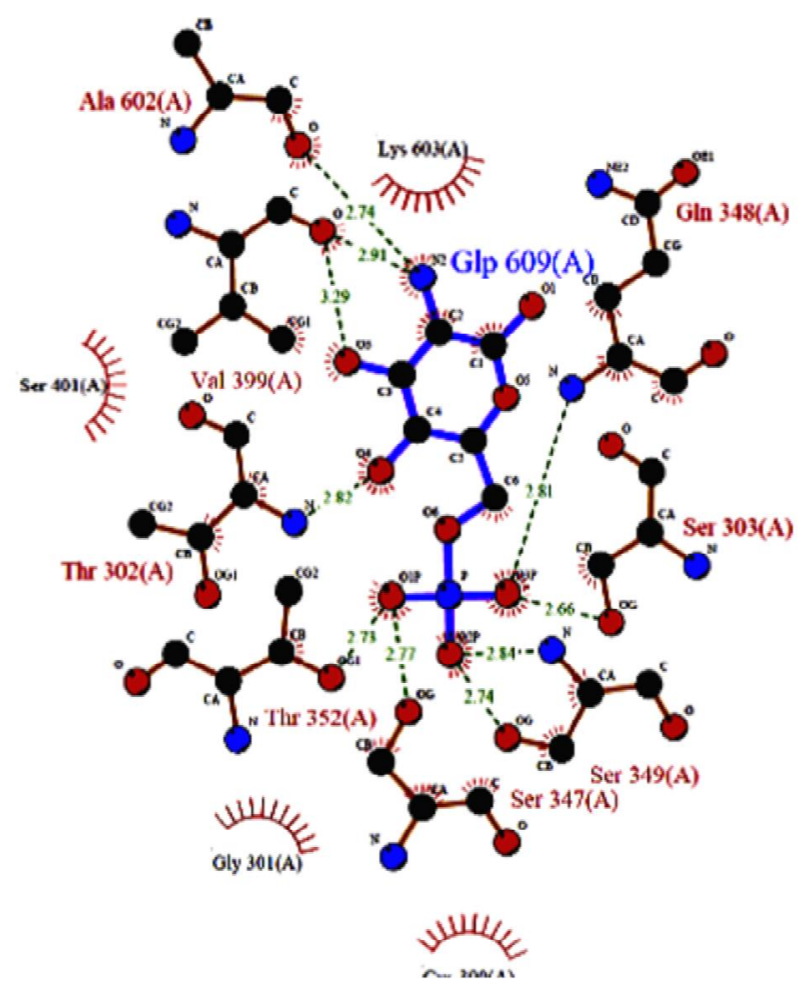

Fig. 2. Ligplot of GlcN-6-P showing the binding of glucosamine-6-phosphate in an active site of enzyme 


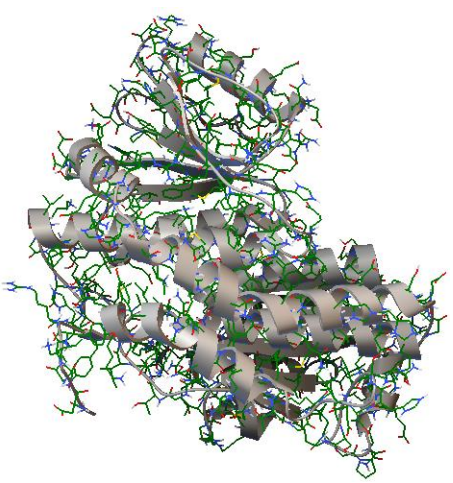

3D structure of GlcN-6-P

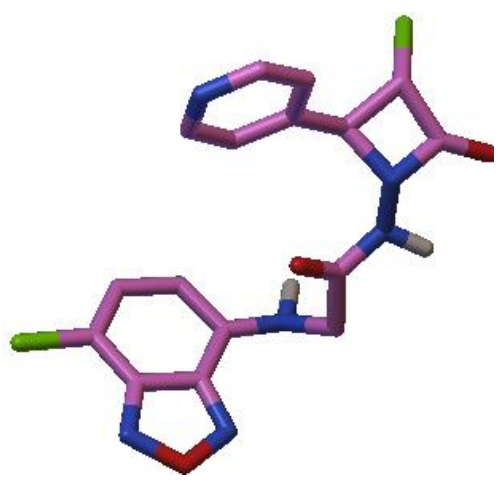

Structure of the compound $\mathbf{8}$

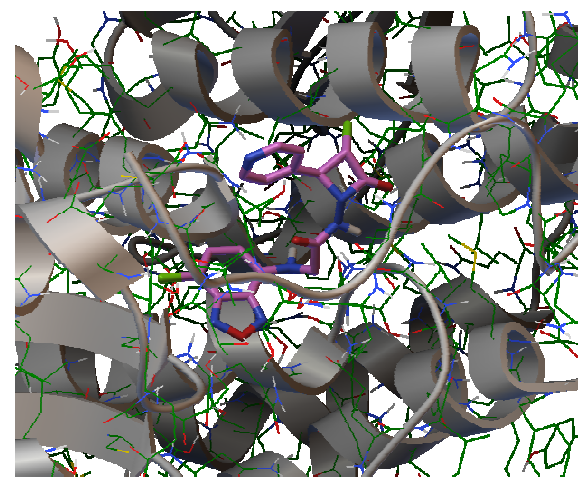

Best generated conformer of the compound 8 inside the binding site of GlcN-6-P

Fig. 3. The docking of the best generated conformer of the compound $\mathbf{8}$ inside the binding pocket of L-glutamine: D-fructose-6phosphate amidotransferase (GlcN-6-P)

Table 2. Docking parameters of the generated conformers of the compound 8 ranking by energy

\begin{tabular}{|c|c|c|c|c|}
\hline Bonding & H-bonds & $\begin{array}{c}\text { Intermolecular energy, } \\
\mathrm{kJ} / \mathrm{mol}\end{array}$ & $\begin{array}{c}\text { Inhibition } \\
\text { constant, } \mu \mathrm{M}\end{array}$ & $\begin{array}{c}\text { Binding energy, } \\
\mathrm{kJ} / \mathrm{mol}\end{array}$ \\
\hline $\begin{array}{c}\text { Ligand:H:Valine399:O } \\
\text { Serine349:HN:Ligand:N,O }\end{array}$ & 2 & -39.98 & 1.23 & -33.74 \\
\hline $\begin{array}{c}\text { Ligand:H: Glutamic acid 488:OE2 } \\
\text { Lysine603:HZ3:Ligand:O } \\
\text { Alanine 602:HN:Ligand:O } \\
\text { Serine 401:HG:Ligand:N }\end{array}$ & 4 & -39.48 & 1.52 & -33.24 \\
\hline- & & & & \\
\hline- & 0 & -38.60 & 2.15 & -32.36 \\
\hline- & 0 & -38.22 & 2.50 & -31.99 \\
\hline- & 0 & -36.80 & 4.45 & -30.56 \\
\hline- & 0 & -36.55 & 4.91 & -30.31 \\
\hline- & 0 & -35.55 & 7.37 & -29.31 \\
\hline- & 0 & -34.21 & 12.69 & -27.97 \\
\hline- & 0 & -32.36 & 26.76 & -26.12 \\
\hline & 0 & -30.73 & 51.84 & -24.49 \\
\hline
\end{tabular}

\section{Conclusions}

A series of benzooxadiazole derivatives were prepared and their structures were confirmed by $(\mathrm{C}, \mathrm{H}, \mathrm{N})$ elemental and spectral analyses. The resulting oxadiazoles were evaluated for their bacterial and fungal activities. The newly synthesized compounds showed high to moderate activity against antimicrobial activities. These characteristics are making them promising compounds that might be used in developing new types of drugs to treat bacterial and fungal diseases. The docking study, carried out by Autodock 4.2, was used to explain the binding affinity of the discovered potent inside the active residues of glucosamine-6-phosphate synthase and the target enzyme for the antimicrobial agents.

\section{Acknowledgments}

The authors would like to thank Mustansiriyah University (www.uomustansiriyah.edu.iq) and Dijlah University College, Baghdad, Iraq for their support in the present work.

\section{References}

[1] Podolsky, S.H. The Evolving Response to Antibiotic Resistance (1945-2018). Palgrave Commun. 2018, 4, 124.

https://doi.org/10.1057/s41599-018-0181-x

[2] Nagaraja, A.; Puttaiahgowda, Y.M.; Kulal, A.; Parambil, A.M.; Varadavenkatesan, T. Synthesis, Characterization, and Fabrication of Hydrophilic Antimicrobial Polymer Thin Film Coatings. Macromol. Res., 2019, 27, 301-309. https://doi.org/10.1007/s13233019-7040-5 
[3] Yıldırım, I.; Aktaş, A.; Celepci D.B.; Kırbağ, S.; Kutlu, T.; Gök, Y.; Aygün, M. Synthesis, Characterization, Crystal Structure, and Antimicrobial Studies of 2-Morpholinoethyl-Substituted Benzimidazolium Salts and Their Silver(I)-N-Heterocyclic Carbene Complexes. Res. Chem. Intermediat. 2017, 43, 6379-6393. https://doi.org/10.1007/s11164-017-2995-3

[4] Murugavel, S.; Sundramoorthy, S.; Subashini, R.; Pavan, P. Synthesis, Characterization, Pharmacological, Molecular Modeling and Antimicrobial Activity Evaluation of Novel Isomer Quinoline Derivatives. Struct. Chem. 2018, 29, 1677-1695.

https://doi.org/10.1007/s11224-018-1149-6

[5] Kavitha, S.; Kannan, K.; Ghanavel, S. Synthesis,

Characterization and Biological Evaluation of Novel 2,5substituted1,3,4 Oxadiazole Derivatives. Saudi Pharm. J. 2017, 25, 337-345. https://doi.org/10.1016/j.jsps.2016.07.004

[6] Modi, V.; Modi, P. Oxadiazole: Synthesis, Characterization and Biological Activities. J. Saudi Chem. Soc. 2012, 16, 327-332. https://doi.org/10.1016/j.jscs.2011.12.017

[7] Ajay Kumar, K.; Lokeshwari, D.; Pavithra, G.; Vasanth Kumar, G. 1,2,4-Oxadiazoles: A Potential Pharmacological Agents-An Overview. Res. J. Pharm. Technol. 2012, 5, 1490-1496.

[8] Parin, V.K.; Rakesh, S.R.; adhuri H., J.M.; Sonali, P.; Pollavi, P.M. Greener Synthesis of Some Bioactive Res. J. Pharm. Technol., 2016, 9, 1433-1440. https://doi.org/10.5958/0974360X.2016.00277.8

[9] Muhammed, K.M.; Ayad, S.H., Nihad, I.T. Preparation and Identification of Some New Compounds 1,3,4-Oxidiazole

Derivatives Using Grinding Technique. Res. J. Pharm. Technol. 2018, 11, 4272-4276. https://doi.org/10.5958/0974360X.2018.00783.7

[10] Golmohhamadi, F.; Balalaie, S.; Hamdan, F.; Maghari, S. Efficient Synthesis of Novel Conjugated 1,3,4-Oxadiazole-Peptides. New J. Chem. 2018, 42, 4344-4351.

https://doi.org/10.1039/C7NJ04720G

[11] Baijika P., Akash M., Midhula C., Shadiha S. Synthesis and

Biological Activities of 1, 3, 4-Oxadiazole Derivatives: A Review of Literature. Int. J. Adv. Res. 2018, 6, 1114-1122. https://doi.org/10.21474/IJAR01/6328

[12] Suman, B.; Sunil, K.; Anu, K.; Saini, V.; Prasad, D.N. 1,3,4Oxadiazole Derivatives: Synthesis, Characterization, Antimicrobial Potential, and Computational Studies. BioMed. Res. Int. 2014, 2014. Article ID 172791. https://doi.org/10.1155/2014/172791

[13] Salahuddin; Mazumder, A.; Shahar Yar, M.; Mazumder, R.; Chakraborthy, G.S.; Ahsan, M.J.; Rahman, M.U. Updates on Synthesis and Biological Activities of 1,3,4-Oxadiazole: A Review. Synth.Commun. 2017, 47, 1805-1847.

https://doi.org/10.1080/00397911.2017.1360911

[14] Shukla, C.; Srivastava, S. Biologically Active Oxadiazole. J. Drug Deliv. Therap. 2015, 5, 8-13.

https://doi.org/10.22270/jddt.v5i6.1100

[15] Bondock, S.; Adel, S.; Etman, H.; Badria, F. Synthesis and Antitumor evaluation of Some New 1,3,4-Oxadiazole-Based Heterocycles. Eur. J. Med. Chem. 2012, 48, 192-199. https://doi.org/10.1016/j.ejmech.2011.12.013

[16] Patel, K.; Prajapati, S.; Panchal, S.N.; Patel, H.D. Review of Synthesis of 1,3,4-Oxadiazole Derivatives. Synth. Commun. 2014, 44, 1859-1875. https://doi.org/10.1080/00397911.2013.879901 [17] Ng, Y.P.; Chen, Y.; Hu, Y.; Ip, F.C.F.; Ip, N.Y. Olean-12Eno[2,3-c] [1,2,5]Oxadiazol-28-Oic Acid (OEOA) Induces G1 Cell Cycle Arrest and Differentiation in Human Leukemia Cell Lines. PLoS ONE, 2013, 8, e63580.

https://doi.org/10.1371/journal.pone.0063580
[18] Desai, N.C.; Bhatt, N.; Somani, H.; Trivedi, A. Synthesis, Antimicrobial and Cytotoxic Activities of Some Novel Thiazole Clubbed 1,3,4-Oxadiazoles. Eur. J. Med. Chem. 2013, 67, 54-59. https://doi.org/10.1016/j.ejmech.2013.06.029

[19] Khalillulah, H.; Khan, S.; Nomani, M.S.; Ahmed, B. Synthesis, Characterization and Antimicrobial Activity of Benzodioxane Ring Containing 1,3,4-Oxadiazole Derivatives. Arab. J. Chem. 2016, 9 , S1029-S1035. https://doi.org/10.1016/j.arabjc.2011.11.009 [20] Khan, S.; Imam; M.; Ahmad, A.; Basha, S.H.; Husain, A. Synthesis, Molecular Docking with COX 1\& II Enzyme, ADMET Screening and In Vivo Anti-Inflammatory Activity of Oxadiazole, Thiadiazole and Triazole Analogs of Felbinac. J. Saudi Chem. Soc. 2018, 22, 469-484. https://doi.org/10.1016/j.jscs.2017.05.006 [21] Iyer, V.B.; Gurupadayya, B.; Koganti, V.S.; Inturi, B.; Chandan, R.S. Design, Synthesis and Biological Evaluation of 1,3,4-Oxadiazoles as Promising Anti-Inflammatory Agents. Med. Chem. Res. 2017, 26, 190-204. https://doi.org/10.1007/s00044-0161740-6

[22] Chen, Y.; Xu, X.; Liu, X.; Yu, M.; Liu, B-F.; Zhang, G. Synthesis and Evaluation of a Series of 2-Substituted-5-

Thiopropylpiperazine (Piperidine)-1,3,4-Oxadiazoles Derivatives as Atypical Antipsychotics. PLoS ONE 2012, 7, e35186.

https://doi.org/10.1371/journal.pone.0035186

[23] Harish, K.P.; Mohana, K.N.; Mallesh, L.; Prasanna Kumar, B.N. Synthesis of Novel 1-[5-(4-methoxy-phenyl)-[1,3,4]oxadiazol2-yl]-Piperazine Derivatives and Evaluation of Their In Vivo Anticonvulsant Activity. Eur. J. Med. Chem. 2013, 65, 276-283. https://doi.org/10.1016/j.ejmech.2013.04.054

[24] Shakir, R.M.; Ariffin, A.; Abdulla, M.A. Synthesis of New 2,5Di-substituted 1,3,4-Oxadiazoles Bearing 2,6-Di-tert-butylphenol Moieties and Evaluation of Their Antioxidant Activity. Molecules 2014, 19, 3436-3449. https://doi.org/10.3390/molecules 19033436 [25] Hajimahdi, Z.; Zarghi, A.; Zabihollahi, R.; Aghasadegh M.R. Synthesis, Biological Evaluation, and Molecular Modeling Studies of New 1,3,4-Oxadiazole- and 1,3,4-Thiadiazole-Substituted 4-Oxo4H-Pyrido[1,2-A]Pyrimidines as Anti-HIV-1 Agents. Med. Chem. Res. 2013, 22, 2467-2475. https://doi.org/10.1007/s00044-012$0241-5$

[26] Pitasse-Santos, P.; Sueth-Santiago; V.; Lima; M.E.F. 1,2,4- and 1,3,4-Oxadiazoles as Scaffolds in the Development of Antiparasitic Agents. J. Braz. Chem. Soc. 2018, 29, 435-456.

https://doi.org/10.21577/0103-5053.20170208

[27] Dighe, N.S.; Shinde, P.; Anap, H.; Bhawar, S.; Musmade, D.S. QSAR Study and Synthesis of Some New 2, 5-Disubstituted 1, 3, 4Oxadiazole Derivatives as Anti-Microbial and Anti-Inflammatory Agents. Asian J. Pharm. Res. [Online] 2014, 4 (4), 174-179. https://asianjpr.com/AbstractView.aspx?PID=2014-4-4-2 (accessed October 12, 2019)

[28] Paun, A.; Hadade, N.D.; Paraschivescu, C.C.; Matache, M. 1,3,4-Oxadiazoles as Luminescent Materials for Organic Light Emitting Diodes via Cross-Coupling Reactions. J. Mater. Chem. C 2016, 37, 8596-8610. https://doi.org/10.1039/C6TC03003C [29] Chidirala, S.; Hidayath, U.; Valaboyu, A; Kiran, M.R.; Mohanty, M.E.; Satyanarayan, M.N.; Umesh, G.; Bhanuprakash, K.; Rao, V.J. Pyrene-Oxadiazoles for Organic Light-Emitting Diodes: Triplet to Singlet Energy Transfer and Role of Hole-Injection/HoleBlocking Materials. J. Org. Chem. 2016, 81, 603.

https://doi.org/10.1021/acs.joc.5b02423

[30] Wei, H.; He, C.; Zhang, J.; Shreeve, J.M. Combination of 1,2,4-Oxadiazole and 1,2,5-Oxadiazole Moieties for the Generation of High-Performance Energetic Materials. Angew. Chem. Int. Ed. 2015, 54, 9367-9371. https://doi.org/10.1002/anie.201503532 
[31] Han, J.; Wang, Q.; Chang, X-Y.; Zhu, L-R.: Fluorescent Liquid Crystalline Compounds with 1,3,4-Oxadiazole and

Benzo[b]thiophene Units. Liq. Cryst. 2012, 39, 669-674.

https://doi.org/10.1080/02678292.2012.671966

[32] Cao, Z.; Tang, Y.; Cang, H.; Xu, J.; Lu, G.; Jing, W. Novel Benzimidazole Derivatives as Corrosion Inhibitors of Mild Steel in the Acidic Media. Part II: Theoretical Studies. Corros. Sci. 2014, 83, 292-298. https://doi.org/10.1016/j.corsci.2014.02.025

[33] Bearne, S.; Blouin, C. Inhibition of Escherichia coliGlucosamine-6-phosphate Synthase by Reactive Intermediate Analogues. The Role of the 2-Amino Function in Catalysis. J. Biol. Chem. 2000, 275, 135-140. https://doi.org/10.1074/jbc.275.1.135 [34] Morris, G.; Goodsell, D.; Halliday, R.; Huey, R.; Hart, W.E.; Belew, R.K.; Olson, A.J. Automated Docking Using a Lamarckian Genetic Algorithm and an Empirical Binding Free Energy Function. J. Comput. Chem. 1998, 19, 1639-1662.

https://doi.org/10.1002/(SICI)1096-

987X(19981115)19:14\%3C1639::AID-JCC10\%3E3.0.CO;2-B

[35] Al-Hassani, R.A.M. Synthesis, Characterization, Antimicrobial and Theoretical Studies of V(IV), $\mathrm{Fe}(\mathrm{III}), \mathrm{Co}(\mathrm{II}), \mathrm{Ni}(\mathrm{II}), \mathrm{Cu}(\mathrm{II})$, and $\mathrm{Zn}$ (II)Complexes with Bidentate (NN) Donar Azo Dye Ligand. Baghdad Sci. J. 2016, 13, 0793.

https://doi.org/10.21123/bsj.13.4.793-805

[36] Nief, O.A.; Salman, H.; Ahamed, L.S. Synthesis, Characterization, Biological Activity Studies of Schiff Bases and 1,3-Oxazipene Derived from 1,1 -Bis (4-aminophenyl) -4-Phenyl Cyclohexane. Iraqi J. Sci. 2017, 58, 1998-2011.

https://doi.org/10.24996/ijs.2017.58.4B.2

[37] Greenwood, D.; Slack, R.; Peurtherer, J.; Barer, M. Medical Microbiology: A Guide to Microbial Infections: Pathogenesis, Immunity, Laboratory Diagnosis and Control, $17^{\text {th }}$ edn; Churchill Livingstne: Edinburgh, 2007.

[38] Balouiri, M.; Sadiki, M.; Ibnsouda, S. Methods for In Vitro Evaluating Antimicrobial Activity: A Review. J. Pharm. Anal. 2016, 6, 71-79. https://doi.org/10.1016/j.jpha.2015.11.005 [39] Abid, S.; Abdula, A.; Al Marjani, M.; Abdulhameed, Q. Synthesis, Antimicrobial, Antioxidant and Docking Study of Some Novel 3,5-Disubstituted-4,5-dihydro-1H-pyrazoles Incorporating
Imine Moiety. Egypt. J. Chem. 2019, 62, 739-749. https://doi.org/10.21608/EJCHEM.2018.5804.1498

[40] Teplyakov, A.; Obmolova, G.; Badet-Denisot, M.A.; Badet, B.; Polikarpov, I. Involvement of the C Terminus in Intramolecular Nitrogen Channeling in Glucosamine 6-Phosphate Synthase: Evidence from A 1.6 A Crystal Structure of the Isomerase Domain. Structure 1998, 6, 1047-1055. https://doi.org/10.1016/S09692126(98)00105-1

Received: December 29, 2019 / Revised: February 11, 2020 / Accepted: May 14, 2020

\section{СИНТЕЗ, ХАРАКТЕРИСТИКА, АНТИМІКРОБНІ ДОСЛІДЖЕННЯ ТА МОЛЕКУЛЯРНИЙ ДОКІНГ БЕНЗООКСАДІАЗОЛЬНИХ ПОХІДНИХ}

Анотація. Синтезовано серію нових 1,2,5-оксадіазольних сполук, отриманих з 4-хлор-7-нітро-бензо 1,2,5-оксадіазолу з використанням різних методик. Отримані похідні охарактеризовані, а їх структури підтверджені за допомогою Фур ‘ $\epsilon$ спектроскопії та ЯМР-аналізу. Визначено антибактеріальну та протигрибкову активність всіх компонентів щодо чотирьох видів патогенних бактерій: S.aureus, S.epidermidis (як грамнегативні бактеріi), E.coli, Klebsiella spp. (як грампозитивні бактеріï) та грибка Candida albicans з використанням методу дифузії в агарі. Встановлено, щчо синтезовані похідні оксадіазолу виявляють значну антибактеріальну та помірну протигрибкову активність. Досліджено зв'язування між ефективною синтезованою похідною 8 в активному центрі глюкозамін-6-фосфат синтази. Цільовий фермент для антимікробних засобів одержано за допомогою Autodock 4.2. Встановлено, шо режсии взаємодії генерованих конформерів у центрі зв'язування покрашують результати in vitro. Нові похідні рекомендовано як перспективні антимікробні засоби.

Ключові слова: 1,2,5-оксадіазол, фуразани, антибактеріальні, протигрибкові, докінг. 